\title{
GRUPUGE Perspective: Endoscopic Ultrasound- Guided Fine-Needle Tattooing and Fiducial Placement in Pancreatic Cancer
}

\author{
Susana Marques ${ }^{a} \quad$ Miguel Bispo $^{a} \quad$ Sílvia Leite $^{b} \quad$ Teresa Moreirac $^{c}$ Ana Caldeira ${ }^{d}$ \\ Pedro Moutinho-Ribeiro ${ }^{e}$ Nuno Nunes ${ }^{f}$ on behalf of the Portuguese Group \\ for Ultrasound in Gastroenterology (GRUPUGE) \\ a Department of Gastroenterology and Digestive Endoscopy, Champalimaud Foundation, Lisbon, Portugal; \\ ${ }^{b}$ Department of Gastroenterology, Hospital da Senhora da Oliveira, Guimarães, Portugal; ' ${ }^{\text {Department of }}$ \\ Gastroenterology, Centro Hospitalar Universitário do Porto - Hospital de Santo António, Porto, Portugal; \\ ${ }^{\mathrm{d}}$ Department of Gastroenterology, Hospital Amato Lusitano, Castelo Branco, Portugal; ${ }^{\text {e Department of }}$ \\ Gastroenterology, Centro Hospitalar e Universitário São João, Porto, Portugal; ' Department of Gastroenterology, \\ Hospital do Divino Espírito Santo, Ponta Delgada, Portugal
}

\section{Keywords}

Endoscopic ultrasound-guided fine-needle tattooing ·

Endoscopic ultrasound-guided fiducial placement . Endoscopic ultrasound-guided hydrogel injection. Pancreatic cancer

\section{Abstract}

In the last 2 decades, endoscopic ultrasound (EUS) has become an important procedure for the diagnosis and management of several pancreatic diseases, including pancreatic cancer. This article presents two recently developed EUS-guided techniques for the management of pancreatic cancer: fine-needle tattooing and fiducial placement. Preoperative EUS-guided fine-needle tattooing of small pancreatic tumors helps in precise localization of these lesions during surgery, potentially ensuring adequate margins of resection while preserving healthy pancreatic tissue. In pancreatic cancer patients planned for imaging-guided radiation therapy, EUS-guided fiducial placement improves the accuracy of target delineation during stereotactic body radiation therapy (SBRT). Hydrogel, a new injectable liquid with multimodal visibility recently approved as a liquid fiducial, is currently under investigation in pancreatic head cancer as an EUS-in- jected spacer to potentially reduce SBRT gastrointestinal wall toxicity. In this article, GRUPUGE presents an updated perspective of these two EUS-guided techniques, addressing their current clinical applications and technical aspects and analyzing existing data on their efficacy and safety.

C) 2020 Sociedade Portuguesa de Gastrenterologia Published by S. Karger AG, Basel

\section{Perspectiva Do GRUPUGE: Tatuagem Com Agulha Fina E Marcação Com Fiduciais Guiadas Por Ecoendoscopia No Cancro Do Pâncreas}

\section{Palavras Chave}

Tatuagem com agulha fina guiada por ecoendoscopia . Marcação com fiduciais guiada por ecoendoscopia . Injeção de hidrogel guiada por ecoendoscopia · Cancro do pâncreas

\section{Resumo}

Durante as duas últimas décadas, a ecoendoscopia tornou-se um procedimento importante para o diagnóstico e abordagem de diversas doenças pancreáticas, incluindo karger@karger.com www.karger.com/pjg

Karger $\stackrel{\text { ' }}{5}$

BOPEN ACCESS
(C) 2020 Sociedade Portuguesa de Gastrenterologia Published by S. Karger AG, Basel

This article is licensed under the Creative Commons AttributionNonCommercial-NoDerivatives 4.0 International License (CC BYNC-ND) (http://www.karger.com/Services/OpenAccessLicense). Usage and distribution for commercial purposes as well as any distribution of modified material requires written permission.
Susana Marques

Department of Gastroenterology and Digestive Endoscopy

Champalimaud Foundation, Av. Brasília

PT-1400-038 Lisbon (Portugal)

susana.marques@fundacaochampalimaud.pt 
o cancro do pâncreas. Neste artigo são apresentadas duas técnicas guiadas por ecoendoscopia desenvolvidas recentemente na abordagem do cancro do pâncreas: tatuagem com agulha fina e marcação com fiduciais. A tatuagem pré-operatória com agulha fina guiada por ecoendoscopia de pequenos tumores pancreáticos ajuda na localização precisa destas lesões durante a cirurgia, potencialmente assegurando margens de resseção adequadas e preservando parênquima pancreático saudável. Nos doentes com cancro do pâncreas com indicação para radioterapia guiada por imagem, a marcação com fiduciais guiada por ecoendoscopia melhora a acuidade da radioterapia estereotáxica corporal na delineação do alvo. O hidrogel, um novo líquido injetável com visibilidade multimodal recentemente aprovado como marcador fiducial, está atualmente em investigação como um espaçador injetado por ecoendoscopia no cancro da cabeça do pâncreas para potencialmente reduzir a toxicidade da radioterapia estereotáxica corporal sobre a parede gastrointestinal. Neste artigo, o GRUPUGE apresenta uma perspetiva atualizada destas duas técnicas guiadas por ecoendoscopia, abordando as suas atuais aplicações clínicas e aspetos técnicos e analisando os dados existentes sobre a sua eficácia e segurança.

(๑) 2020 Sociedade Portuguesa de Gastrenterologia Publicado por S. Karger AG, Basel

\section{Introduction}

In the last two decades, endoscopic ultrasound (EUS) has become an important procedure for the diagnosis and management of several pancreatic diseases, including pancreatic cancer. EUS-guided interventional procedures have expanded the applications of EUS in pancreatic cancer and are changing its current management.

In this chapter, the Portuguese Group for Ultrasound in Gastroenterology presents an updated perspective of three recently developed EUS-guided techniques for the management of pancreatic cancer: fine-needle tattooing, fiducial placement, and hydrogel injection, addressing their current clinical applications and technical aspects and analyzing existing data on their efficacy and safety.

A systematic literature search was performed until January 2020 using PubMed, Medline, Scopus, and Google, using the keywords "pancreatic cancer," "endoscopic ultrasound-guided fine-needle tattooing," "endoscopic ultrasound-guided fiducial placement," and "endoscopic ultrasound-guided hydrogel injection." Prospective/comparative studies and international consensus statements/management guidelines were preferred. The

EUS-FNT and Fiducial Placement in

Pancreatic Cancer final work was revised and approved by all of the members of the Governing Board of the Portuguese Group for Ultrasound in Gastroenterology (GRUPUGE).

\section{EUS-Guided Fine-Needle Tattooing}

Precise localization of pancreatic tumors undergoing surgery is critical to achieve adequate margins of resection (R0 resection) and preserve healthy pancreatic tissue, therefore minimizing the risk of endocrine and exocrine pancreatic insufficiency. Nevertheless, precise localization of small pancreatic tumors such as neuroendocrine lesions during surgery, particularly during laparoscopic distal pancreatectomy, can be difficult because of the decreased tactile ability of laparoscopy and the homogeneous appearance of the pancreas and surrounding retroperitoneal fat. Inability to localize the tumor via a laparoscopic approach can lead to conversion to an open procedure, with conversion rates as high as $30 \%$ in one multicenter study [1]. Therefore, intraoperative ultrasound (US) has been used to locate small pancreatic lesions, with reported success rates between 60 and 90\% [1-5]. However, laparoscopic US probes frequently do not provide the resolution of the standard intraoperative probes, and there are several reports of surgeons being unable to identify lesions during laparoscopy despite use of intraoperative US [1, 6-8].

Preoperative EUS-guided fine-needle tattooing (EUSFNT) helps in the precise localization of pancreatic lesions during surgery and it is now becoming a standard procedure at several institutions for patients with distal pancreatic lesions and planned laparoscopic distal pancreatectomy. A retrospective cohort study comparing EUS-FNT followed by laparoscopic distal pancreatectomy and laparoscopic distal pancreatectomy alone showed that EUS-FNT was technically feasible and the tattoo was visible during laparoscopy in all patients [9]. In all cases an $\mathrm{R} 0$ resection was achieved and no complications associated with EUS-FNT were reported [9]. Also, EUS-FNT was associated with a decreased operative time compared to non-tattooed patients. Therefore, the authors concluded that preoperative EUS-FNT of distal pancreatic lesions is feasible, efficacious, and safe in patients undergoing laparoscopic distal pancreatectomy. Another interesting result of this study is that the mean time from EUS-FNT to surgery was 20.3 days (range 3-69). This finding suggests that EUS-FNT does not need to be performed immediately before surgery but it can be performed at the same time of the diagnostic EUS, thus avoiding the risks and costs associated with an additional procedure.

Using a linear array echoendoscope, a 22-gauge fineneedle aspiration (FNA) needle is inserted into the pancre- 
atic parenchyma $3-5 \mathrm{~mm}$ to the patient's right of the lesion (towards the pancreatic head). A total of $1-5 \mathrm{~mL}$ sterile purified carbon particles (GI Spot; GI Supply, Camp Hill, $\mathrm{PA}, \mathrm{USA}$ ) is injected under EUS guidance in $0.5-\mathrm{mL}$ increments anterior to the main pancreatic duct and withdrawing the needle slowly from the posterior to the anterior direction. During injection, a hyperechoic blush can be visualized in real time at the tip of the needle. Periprocedural antibiotics followed by 3 days of oral antibiotics are usually advocated to minimize the infection risk [9]. This technique has two potential advantages over direct injection into the tumor. First, inserting the needle into the patient's right side, rather than into the tumor, avoids the risk of tumor seeding along the needle tract. Second, placing the needle 3-5 $\mathrm{mm}$ away from the tumor potentially ensures negative pathology margins (R0 resection) while preserving the maximum amount of pancreatic parenchyma [9]. More studies are needed to determine whether EUS-FNT is associated with improved patient outcomes and lower costs of laparoscopic distal pancreatectomy.

\section{EUS-Guided Fiducial Placement}

Radiation therapy has an important role in the treatment of locally advanced or metastatic pancreatic cancer and can be used alone or in combination with systemic chemotherapy. Advancements in radiation therapy technique contribute to tumor downstaging, improving the chances of a secondary resection, and enhance local control for unresectable disease and palliation of symptoms related to local progression $[10,11]$. Stereotactic body radiation therapy (SBRT) is a recent technique that uses advanced imaging technology to verify the target lesion position before and during radiation therapy, allowing precise delivery of highdose radiation to pancreatic tumors. Major challenges for SBRT included respiratory organ motion and accurate assessment of tumor size and location in real time. SBRT usually relies on fiducial markers to target and track the location of the tumor in real time. This ensures the treatment is delivered to the tumor with high precision while decreasing the toxicity to normal surround tissue $[10,11]$.

Fiducials are radiographically visible markers, usually made of gold, that are inserted into the target lesion. They can be placed surgically or percutaneously under US or computer tomography guidance or endoscopically by EUS. EUS is a minimally invasive procedure that provides an excellent visualization of the pancreas and it is an optimal approach for fiducial placement in pancreatic lesions $[10,11]$.

Various types of fiducial markers (spheres, coils, or seeds) and different delivery systems have been developed. Fiducials can be delivered using a linear array echo- endoscope with 19-gauge or 22-gauge FNA needles or via multifiducial delivery systems $[10,11]$. The 22 -gauge is potentially advantageous over a 19-gauge needle because of its greater flexibility, particularly when used in challenging anatomic locations or postsurgical anatomy [12].

The retrograde or back-loading technique is the most common method used to load the fiducial marker into the EUS needle [13]. The stylet is withdrawn approximately 3 $\mathrm{cm}$. The fiducial marker, which is loaded on a needle carrier, is then inserted into the FNA needle tip. The fiducial is deployed into the needle tip by removing the needle carrier. Sterile bone wax is used to seal the tip of the needle to secure the fiducial. The needle is then advanced down the operating channel of the echoendoscope. Once the needle is inserted into the target lesion, the fiducial is deployed by simultaneously retracting the needle while advancing the stylet. Then, the needle is withdrawn from the operating channel of echoendoscope and reloaded with a new fiducial and the technique is repeated until the desired number of markers has been placed [13]. Generally, at least 3 fiducial markers should be placed on different EUS viewing planes so that the pancreatic tumor borders and planes can be well defined during SBRT simulation and delivery [11]. A potential disadvantage of using the backloading method is the possibility of needle stick injuries, particularly when the FNA needle is reloaded [12].

Another approach to load the FNA needle is by using the anterograde or front-loading technique [12]. In this method, the stylet is removed, the needle tip is sealed with sterile bone wax, and the fiducial marker is inserted into the top of the needle. The stylet is then reinserted and slowly advanced, thereby pushing the fiducial into the distal end of the needle [12]. This technique has two potential advantages over the retrograde or back-loading technique; it not only minimizes needle stick injuries but it also allows a more rapid deployment of multiple fiducials since needle loading can be performed once the needle has been inserted into the target lesion [12].

Fiducial placement under EUS guidance has been reported as feasible, safe, and effective in several studies. The feasibility of EUS-guided fiducial placement for pancreatic cancer has been reported with technical success rates of $90-100 \%$ [14-18]. Reported complications in these studies include mild acute pancreatitis, minor bleeding, vomiting and abdominal pain. Some authors have suggested the use of prophylactic antibiotics during EUSguided fiducial placement, and further studies are needed to validate this recommendation [12]. The rate of fiducial migration is low (7\%) and no migration-related complications have been reported [15]. Other studies have shown 
that fiducial markers improve the accuracy of target delineation during SBRT [19-21]. Furthermore, a recent casecontrol study reported data on comparative outcomes between pancreatic cancer patients who underwent RT with and without EUS-guided placement of fiducial markers. According to that study's results, a similar treatment effect was achieved with a lower target radiation dose (2862 vs. 3712 cGy; $p=0.004$ ) and fewer sessions ( 5 vs. 13 ; $p=$ 0.002 ) utilizing EUS-guided fiducial placement [22].

In light of these promising findings, the most recent international guidelines on pancreatic adenocarcinoma (NCCN version 1.2020) state that, for localized, intact pancreatic cancer (resectable, borderline, and locally advanced), placement of $1-5$ (preferably $\geq 3$ ) gold fiducial markers, preferentially by EUS, may be useful for radiotherapy targeting purposes [23].

Recently, newer preloaded fiducial needles have been developed to overcome some of the previously noted issues associated with the traditional back-loading technique. These new needles are preloaded with 2 (Beacon EUS FNF pre-loaded 19 and 22-gauge needles; Medtronic, Dublin, Ireland) or 4 fiducials (EchoTip Ultra Fiducial 22-gauge needle; Cook Medical, Bloomington, IN, USA) and do not require an assistant to load the fiducials into the needle, therefore potentially reducing needle stick injuries and procedure time [24].

A recent randomized controlled trial assessed the performance of these new preloaded fiducial needles over the traditional back-loaded needles [24]. This trial showed that EUS-guided placement of preloaded fiducials required less time ( 9 vs. 16 min; $p<0.001$ ) compared to back-loaded fiducial, with similar technical success, adverse events, migration rates and visibility during SBRT simulation. These new preloaded fiducial needles may offer the potential for increased procedure efficiency while reducing needle stick injuries [24]. Further studies are required to confirm these findings and to evaluate cost effectiveness.

Hydrogel is a new injectable sterile liquid made of iodinated polyethylene glycol particles (TraceIt Fiducial Marker; Augmenix Inc., Waltham, MA, USA) that has been approved as a liquid fiducial on solid tumors. It is readsorbable, has multimodal visibility, and can be easily injected through 19-gauge FNA needles into the tumor and surrounding tissues with a single puncture [25].

In a report of 2 patients with locally advanced pancreatic cancer, EUS-guided hydrogel injection was feasible and safe and provided adequate visibility during SBRT, and may become an alternative to metal fiducials [25].

Another potential application for EUS-guided hydrogel injection in pancreatic cancer is currently under in-

EUS-FNT and Fiducial Placement in

Pancreatic Cancer vestigation. Despite recent advances in imaging-guided radiotherapy, local gastrointestinal toxicity remains a major limitation for effective dose delivery due to the close proximity of the gastrointestinal wall to the pancreas, particularly the head of the pancreas. In a report of 4 patients with borderline or locally advanced pancreatic cancer planned for radiation therapy, hydrogel was injected under EUS guidance into the pancreatic head-duodenal wall interface to increase the physical distance between the pancreas and the duodenal wall [26]. In that study, this technique was technically feasible and no radiation-induced duodenal toxicity was reported. Further studies are warranted to confirm that hydrogel might me used has a spacer in pancreatic cancer to potentially reduce SBRT gastrointestinal wall toxicity [26].

\section{Discussion and Conclusion}

In recent years, EUS has become an invaluable tool for the diagnosis and management of pancreatic cancer. Recent technical advances have contributed to the development of new EUS-guided techniques for the management of pancreatic cancer, such as fine-needle tattooing and fiducial placement. Due to the fact that these are novel procedures, most published studies have focused on technical success and safety, and data on patient outcomes is limited. Furthermore, there is still a lack of standardization of several technical aspects of both procedures. Hence, more studies, and randomized controlled trials in particular, are needed to further and better evaluate their clinical role and impact in pancreatic cancer management before definite guidelines can be established.

\section{Key Points}

Preoperative EUS-guided fine-needle tattooing of small pancreatic tumors is technically feasible and helps in precise localization of these lesions during surgery, potentially ensuring adequate margins of resection (R0 resection) while preserving healthy pancreatic tissue.

In borderline, locally advanced and metastatic pancreatic cancer planned for imaging-guided radiation therapy, EUS-guided fiducial placement is feasible, safe and effective, improving the accuracy of target delineation and reducing radiation exposure during SBRT. Comparing to the traditional back-loaded needles, new preloaded fiducial needles appear to reduce the procedure time while reducing needle stick injuries.

Hydrogel, a new injectable liquid with multimodal visibility recently approved as a liquid fiducial, is currently 
under investigation in pancreatic head cancer as an EUSinjected spacer to potentially reduce SBRT gastrointestinal wall toxicity.

\section{Conflict of Interest Statement}

All of the authors disclose no personal conflict of interests or financial relationships relevant to this publication.
Funding Sources

None to report.

\section{Author Contributions}

Susana Marques: article concept and design, literature review, and draft of this paper. Miguel Bispo, Sílvia Leite, Teresa Moreira, Ana Caldeira, Pedro Moutinho-Ribeiro, and Nuno Nunes: literature review and critical review of this paper.

\section{References}

1 Ayav A, Bresler L, Brunaud L, Boissel P; SFCL (Société Française de Chirurgie Laparoscopique); AFCE (Association Francophone de Chirurgie Endocrinienne). Laparoscopic approach for solitary insulinoma: a multicentre study. Langenbecks Arch Surg. 2005 Apr;390(2):134-40.

2 Jaroszewski DE, Schlinkert RT, Thompson GB, Schlinkert DK. Laparoscopic localization and resection of insulinomas. Arch Surg. 2004 Mar;139(3):270-4.

3 Berends FJ, Cuesta MA, Kazemier G, van Eijck $\mathrm{CH}$, de Herder WW, van Muiswinkel JM, et al. Laparoscopic detection and resection of insulinomas. Surgery. 2000 Sep;128(3):386-91.

4 Mabrut JY, Fernandez-Cruz L, Azagra JS, Bassi C, Delvaux G, Weerts J, et al.; Hepatobiliary and Pancreatic Section (HBPS) of the Royal Belgian Society of Surgery; Belgian Group for Endoscopic Surgery (BGES); Club Coelio. Laparoscopic pancreatic resection: results of a multicenter European study of 127 patients. Surgery. 2005 Jun;137(6):597-605.

5 Gagner M, Pomp A, Herrera MF. Early experience with laparoscopic resections of islet cell tumors. Surgery. 1996 Dec;120(6):1051-4.

6 Zografos GN, Stathopoulou A, Mitropapas G, Karoubalis J, Kontogeorgos G, Kaltsas G, et al. Preoperative imaging and localization of small sized insulinoma with EUS-guided fine needle tattoing: a case report. Hormones (Athens). 2005 Apr-Jun;4(2):111-6.

7 Ashida R, Yamao K, Okubo K, Sawaki A, Mizuno N, Nakamura T, et al. Indocyanine green is an ideal dye for endoscopic ultrasound-guided fine-needle tattooing of pancreatic tumors. Endoscopy. 2006 Feb;38(2):190-2.

8 Farrell JJ, Sherrod A, Parekh D. EUS-guided fine-needle tattooing for preoperative localization of early pancreatic adenocarcinoma. Gastrointest Endosc. 2009 Jan;69(1):176-7.

9 Lennon AM, Newman N, Makary MA, Edil BH, Shin EJ, Khashab MA, et al. EUS-guided tattooing before laparoscopic distal pancreatic resection (with video). Gastrointest Endosc. 2010 Nov;72(5):1089-94.
10 Chavalitdhamrong D, DiMaio CJ, Siersema $\mathrm{PD}$, Wagh MS. Technical advances in endoscopic ultrasound-guided fiducial placement for the treatment of pancreatic cancer. Endosc Int Open. 2015 Aug;3(4):E373-7.

11 Coronel E, Singh BS, Cazacu IM, Moningi S, Romero L, Taniguchi C, et al. EUS-guided placement of fiducial markers for the treatment of pancreatic cancer. VideoGIE. 2019 Jul;4(9):403-6.

12 Ammar T, Coté GA, Creach KM, Kohlmeier C, Parikh PJ, Azar RR. Fiducial placement for stereotactic radiation by using EUS: feasibility when using a marker compatible with a standard 22-gauge needle. Gastrointest Endosc. 2010 Mar;71(3):630-3.

13 Owens DJ, Savides TJ. EUS placement of metal fiducials by using a backloaded technique with bone wax seal. Gastrointest Endosc. 2009 Apr;69(4):972-3.

14 Majumder S, Berzin TM, Mahadevan A, Pawa R, Ellsmere J, Sepe PS, et al. Endoscopic ultrasound-guided pancreatic fiducial placement: how important is ideal fiducial geometry? Pancreas. 2013 May;42(4):692-5.

15 Sanders MK, Moser AJ, Khalid A, Fasanella KE, Zeh HJ, Burton S, et al. EUS-guided fiducial placement for stereotactic body radiotherapy in locally advanced and recurrent pancreatic cancer. Gastrointest Endosc. 2010 Jun;71(7):1178-84.

16 Park WG, Yan BM, Schellenberg D, Kim J, Chang DT, Koong A, et al. EUS-guided gold fiducial insertion for image-guided radiation therapy of pancreatic cancer: 50 successful cases without fluoroscopy. Gastrointest Endosc. 2010 Mar;71(3):513-8.

17 Varadarajulu S, Trevino JM, Shen S, Jacob R. The use of endoscopic ultrasound-guided gold markers in image-guided radiation therapy of pancreatic cancers: a case series. Endoscopy. 2010 May;42(5):423-5.

18 Dávila Fajardo R, Lekkerkerker SJ, van der Horst A, Lens E, Bergman JJ, Fockens P, et al. EUS-guided fiducial markers placement with a 22-gauge needle for image-guided radiation therapy in pancreatic cancer. Gastrointest Endosc. 2014 May;79(5):851-5.
19 Jayachandran P, Minn AY, Van Dam J, Norton JA, Koong AC, Chang DT. Interfractional uncertainty in the treatment of pancreatic cancer with radiation. Int J Radiat Oncol Biol Phys. 2010 Feb;76(2):603-7.

20 van der Horst A, Wognum S, Dávila Fajardo $\mathrm{R}$, de Jong R, van Hooft JE, Fockens $\mathrm{P}$, et al. Interfractional position variation of pancreatic tumors quantified using intratumoral fiducial markers and daily cone beam computed tomography. Int J Radiat Oncol Biol Phys. 2013 Sep;87(1):202-8.

21 Packard M, Gayou O, Gurram K, Weiss B, Thakkar S, Kirichenko A. Use of implanted gold fiducial markers with MV-CBCT imageguided IMRT for pancreatic tumours. J Med Imaging Radiat Oncol. 2015 Aug;59(4):499506.

22 Dalapathi V, Ullah MA, Aranez JL, Katz A, Qiu H, Bittner K, et al. Tu1386 Clinical outcomes of patients with pancreatic cancer with EUS-guided fiducial placement for radiation therapy. Gastrointest Endosc. 2019;89(6 Suppl):AB603-4.

23 Tempero MA, Malafa MP, Al-Hawary M, et al. Pancreatic Adenocarcinoma, Version 1.2020. NCCN; 2019.

24 Machicado JD, Obuch JC, Goodman KA, Schefter TE, Frakes J, Hoffe S, et al. Endoscopic Ultrasound Placement of Preloaded Fiducial Markers Shortens Procedure Time Compared to Back-Loaded Markers. Clin Gastroenterol Hepatol. 2019 Dec;17(13):2749-2758.e2.

25 Ussui V, Kuritzky N, Berzosa M. EUS -guided liquid fiducial placement for stereotactic radiotherapy in pancreatic cancer: feasibility study. Endosc Ultrasound. 2018 Mar-Apr; $7(2): 135-6$.

26 Kerdsirichairat T, Narang AK, Thompson E, Kim SH, Rao A, Ding K, et al. Feasibility of Using Hydrogel Spacers for Borderline-Resectable and Locally Advanced Pancreatic Tumors. Gastroenterology. 2019 Oct;157(4): 933-5. 